\title{
NEGÓCIOS JURÍDICOS PROCESSUAIS APLICADOS AOS CONTRATOS DE LOCAÇÃO DE IMÓVEIS URBANOS ${ }^{1}$
}

LEGAL BUSINESS PROCEDURES APPLICABLE TO LEASE CONTRACTS OF URBAN

BUILDINGS

Isabella Branquinho ARANTES, ${ }^{2}$

Victor Hugo Polim MILAN ${ }^{3}$

ISSUE DOI: $10.21207 / 2675-0104.2018 .735$

\begin{abstract}
RESUMO
O presente trabalho disserta sobre a aplicação do negócio jurídico processual, previsto nos artigos 190 e 191 do Código de Processo Civil, aos contratos de locação de imóveis urbanos, buscando estabelecer algumas hipóteses em que é possível as partes convencionarem os seus direitos, ônus e deveres. De início, aborda a previsão do negócio jurídico processual no novo CPC, apontando os requisitos legais para a sua validade, encontrados tanto na legislação processual civil, quanto na legislação civil. Apresenta, em complemento, alguns dos princípios processuais e contratuais mais importantes quando se trata de Processo e de Contrato, a fim de delimitar o âmbito de aplicação das convenções processuais no caso concreto. Desprende, por fim, a possibilidade ou não de determinadas transações contratuais, concluindo se capazes de produzir pleno efeito, no caso de validação pelo juiz, ou se defesas por colidirem com algum Princípio ou requisito legal. Para tanto, utiliza ampla pesquisa bibliográfica,
\end{abstract}

\footnotetext{
${ }^{1} \mathrm{O}$ presente artigo sintetiza a monografia de conclusão da pesquisa, realizada para o Programa Interno de Bolsas de Iniciação Científica (PIBIC 2017-2018) da Faculdade de Direito de Franca (FDF), Franca/SP.

${ }^{2}$ Discente da Faculdade de Direito de Franca (FDF), Franca/SP. Bolsista do Programa Interno de Iniciação Científica (PIBIC 2017-2018).

${ }^{3}$ Advogado, Mestre em Direito pela Universidade Estadual Paulista UNESP - "Júlio de Mesquita Filho", campus Franca-SP (2013). Graduado em Direito pela Universidade Estadual Paulista UNESP "Júlio de Mesquita Filho" Faculdade de Ciências Humanas e Sociais - FCHS campus Franca-SP em 2009. Professor da Fundação Educacional de Ituverava - SP e Professor Convidado Colaborador da Faculdade de Direito de Franca - SP.
} 
unindo os ramos de direito constitucional, processual e civil a fim de balizar a atuação das partes e garantir que as normas de ordem públicas serão respeitadas.

Palavras-chave: Negócios Jurídicos Processuais. Código de Processo Civil. Código Civil. Contratos. ABSTRACT

The present work deals with the application of the legal process, provided for in Articles 190 and 191 of the Code of Civil Procedure, to contracts for the leasing of urban properties, seeking to establish some hypotheses in which it is possible for the parties to agree on their rights, burdens and duties. Initially, it deals with the prediction of the legal business process in the new CCP, pointing out the legal requirements for its validity, found both in civil procedural legislation and in civil legislation. In addition, it sets out some of the most important procedural and contractual principles in the case of the Procedure and the Contract, in order to delimit the scope of the procedural agreements in this case. Finally, it establishes the possibility or not of certain contractual transactions, concluding that they are capable of producing full effect, in the case of validation by the judge, or if they defend themselves because they conflict with some Principle or legal requirement. To do so, it uses extensive bibliographical research, joining the branches of constitutional, procedural and civil law in order to validate the performance of the parties and ensure that the norms of public order will be respected.

Keywords: Legal Business Process. Code of Civil Procedure. Civil Code. Contracts.

\section{INTRODUÇÃO}

Trata-se o negócio jurídico processual de um instituto nascido oficialmente com o advento do novo Código de Processo Civil de 2015, cuja proposta é trazer as partes ao seio do processo, de modo que possam utilizar de maior autonomia para convencionar sobre as particularidades do procedimento judicial, ajustando-o às particularidades de cada um. Com o negócio jurídico processual, os litigantes - ou até mesmo os interessados, quando ainda não houver lide - podem transacionar direitos, ônus e deveres, moldando o processo às suas necessidades.

O Código de Processo Civil de 1973 previa algumas hipóteses de negócios processuais típicos, como o acordo e a suspensão do processo, porém se limitava a apenas alguns casos, enquanto o novo CPC estabeleceu uma cláusula geral, que em redação tão diminuta amplia os leques de possibilidades na medida da criatividade de cada um.

Enquanto parte da doutrina mantém-se favorável pela previsão inédita do dispositivo, o qual explicita a intenção do legislador ao estabelecer a nova normativa processual civil, buscando maior cooperação e atuação das partes, os demais autores demonstram-se receosos pela amplitude infinita de negócios jurídicos processuais. Isso porque os artigos 190 e 191 do novo CPC não trouxeram rol algum, nem ao menos exemplificativo, dispondo que alguns requisitos a serem observados e estabelecendo que as convenções processuais devem passar pelo crivo do juiz. 
Por certo que, em se tratando de matéria recente, não há verdade absoluta a ser explorada. Para ponderar, portanto, quais hipóteses são válidas ou não em um contrato de locação de imóvel urbano, regente pela Lei n. $^{\circ} 8.245 / 91$, há que se realizar um estudo conjunto do Direito Processual Civil, não se olvidando do caráter Constitucional de alguns princípios, ao Direito Civil, em especial na matéria de contratos.

Ademais, somente com a consolidação da jurisprudência é que haverá maior segurança para afirmar quais convenções são possíveis, haja vista que a doutrina somente introduz hipóteses abstratas, devendo o juiz ter a última palavra no caso concreto.

Assim, utilizando-se do estudo principiológico e da pesquisa bibliográfica, abordar-se-á, de início, o texto legal, buscando estabelecer o conceito e os requisitos legais dos negócios jurídicos processuais. Em complemento, serão estudados os principais princípios que se encaixam à temática, dentre os princípios regentes do novo Código de Processo Civil e os princípios contratuais. Por fim, serão dissecadas algumas hipóteses de convenções processuais em contratos de locação de imóveis com base nos requisitos legais e princípios já observados, finalizando com alguns julgados do Tribunal de Justiça do Estado de São Paulo que discutem as convenções processuais no caso concreto.

\section{DA NORMATIVA DO NEGÓCIO JURÍDICO PROCESSUAL}

A reforma do Código de Processo Civil, por meio da lei n. $^{\circ}$ 13.105, de 16 de março de 2015, foi aprovada com o intuito de contornar a morosidade dos procedimentos judiciais, causada pela enorme quantidade de ações judiciais que atolam o Poder Judiciário. Com os princípios da celeridade e da cooperação, a intenção do legislador foi trazer as partes ao bojo processual para que tomem a lide para si, na contramão da "cultura do processo", na qual as partes são incapazes de dialogarem por si e de resolverem os seus próprios problemas.

Como exemplos da roupagem do novo CPC, tem-se a audiência de conciliação e mediação, a ser realizada antes mesmo de se ofertar a citação, e o instituto do negócio jurídico processual, a ser dissecado a seguir. 


\section{$2.1 \quad$ DOS CONCEITOS PRELIMINARES}

O negócio jurídico processual pode ser conceituado como uma transação realizada entre as partes, litigantes ou não, que moldam o procedimento judicial atual ou futuro de acordo com suas necessidades, acordando direitos, deveres e ônus processuais.

Para alguns doutrinadores, em especial Antonio do Passo Cabral, o termo "negócio jurídico processual" traz uma ideia de antagonismo, que vai de encontro à verdadeira intenção do dispositivo, que é integrar as partes; enquanto o termo "convenção processual" seria mais adequado justamente por expor que as partes estão de comum acordo ${ }^{4}$.

Não obstante a nomenclatura "negócios jurídicos processuais", referidas convenções podem ser realizadas em contratos, portanto antes de instaurada a lide, ou já no bojo processual, sendo clara a redação do artigo 190 quanto ao momento da avença. As convenções estipuladas em cláusulas contratuais podem também ser chamadas "negócios jurídicos pré-processuais".

Em complemento, o artigo 191 traz um negócio processual típico intitulado calendário processual. $\mathrm{O}$ dispositivo permite que os litigantes estabeleçam datas para a realização de determinados atos processuais, sendo dispensados de intimação para tal. A calendarização do processo deve contar não somente com a homologação do juiz, como também sua efetiva participação, haja vista que cabe a ele ponderar sobre a pertinência do calendário almejado, bem como a possibilidade do juízo em cumpri-lo. Conquanto extremamente convidativo, no momento atual não se verifica possível, já que as unidades judiciais não conseguiriam seguir datas prédeterminadas em um processo quando há milhares de outros parados e demandando atenção.

Por fim, ainda quanto à conceituação do negócio jurídico processual, a normativa civilista dispõe sobre duas categorias de negócios jurídicos: unilaterais ou bilaterais. O artigo 190 não expressa essa classificação, mas não se obsta à realização de ambos os tipos de negócios jurídicos processuais. Ressalta-se, no entanto, que a parte só se obriga no limite de sua manifestação de vontade.

Nas palavras de Luiz Rodrigues Wambier e Eduardo Talamini:

A rigor, os negócios jurídicos processuais podem ser atos bilaterais ou unilaterais. O negócio processual unilateral é a expressão de vontade de um único sujeito (ou polo de sujeitos), que

\footnotetext{
${ }^{4}$ CABRAL, Antonio do Passo. Convenções processuais. Salvador: Editora Juspodivm, 2016. p. 56.
} 
unilateralmente dispõe de alguma posição jurídica processual de que era titular. O negócio processual bilateral é fruto do ajuste de vontade de dois ou mais sujeitos (ou polos de sujeitos), que coordenadamente dispõem sobre suas respectivas posições processuais ${ }^{5}$.

Em se estipulando hipóteses de negócios judiciais atípicos, não previstos na lei, é possível observar que a maioria tratará de renúncia a algum direito ou ônus processual, isso porque, nas palavras de Cristiano Chaves de Farias e Nelson Rosenvald, a renúncia pode ser entendida como o "despojamento do direito, sem transferência, com exceção de alguns direitos de caráter irrenunciável, como os direitos da personalidade" $"$.

Assim, convencionando sobre seus deveres, ônus e direitos, as partes acabam por ceder certos direitos.

A renúncia, que exige apenas uma manifestação de vontade para se completar, poderá ser o ponto norteador de uma convenção processual no momento em que o negócio jurídico processual estabeleça renúncia por ambas as partes, por exemplo na renúncia bilateral de recurso, que terá sua validade questionada posteriormente.

A renúncia, que geralmente pode ser aplicada, deve passar pelo crivo de diversos requisitos e princípios estudados a seguir para que possa ter a validade confirmada pelo juiz quando das convenções processuais.

\subsection{DOS REQUISITOS LEGAIS}

O negócio jurídico processual, conquanto previsto no Código de Processo Civil, é uma espécie de negócio jurídico constante no Código Civil em seu Livro III, dos Fatos Jurídicos.

Deste modo, deve respeitar não só os requisitos legais trazidos pelo códex processual civil quanto às normas do ordenamento civil, o que exige um estudo conjunto.

\subsubsection{CAPACIDADE DO AGENTE}

\footnotetext{
${ }^{5}$ WAMBIER, Luiz Rodrigues; TALAMINI, Eduardo. Curso avançado de processo civil: teoria geral do processo. 16. ed. São Paulo: Revista dos Tribunais, 2016. p. 514.

${ }^{6}$ FARIAS, Cristiano Chaves de; ROSENVALD, Nelson. Curso de direito civil: parte geral e LINDB. 13. ed. São Paulo: Atlas, 2015. p. 495.
} 
Tal requisito diz respeito ao elemento volitivo, previsto no inciso I do artigo 104 e no artigo 166 do Código Civil, exigindo que a parte tenha capacidade para manifestar a declaração de vontade, sob pena de não ser reconhecida como válida no mundo jurídico.

O artigo 190 do Código de Processo Civil prevê mais além, limitando a estipulação de negócios jurídicos processuais àqueles plenamente capazes, sendo essa capacidade a de contratar, exigindo plena capacidade das partes.

Não é suficiente, portanto, que os absolutamente incapazes (artigo 3. ${ }^{\circ}$ do Código Civil) e os relativamente incapazes (artigo 4. ${ }^{\circ}$ do Código Civil) estejam representados e assistidos, respectivamente. Para convencionar sobre os ônus, deveres e direitos processuais, a capacidade deve ser plena.

Em relação às pessoas jurídicas, em não havendo vedação legal, considera-se válida a convenção processual realizada por seus representantes, desde que com autorização judicial ou da assembleia ${ }^{7}$.

\subsubsection{OBJETO LÍCITO}

Extrai-se do inciso II do artigo 104 do Código Civil que o objeto deve ser lícito, possível, determinado ou determinável.

Objeto lícito é aquele não defeso em lei, devendo respeitar os costumes, a ordem pública e a boa fé.

Objeto possível é aquele palpável tanto no plano físico quanto no jurídico. O objeto juridicamente possível o é quando a lei não veda o seu conteúdo, enquanto o fisicamente possível o é quando desimpedido o seu alcance.

Já o objeto determinado ou determinável é aquele especificado de maneira clara, direta e concisa, fundamental em um contrato.

Tendo em vista que ainda não é possível catalogar todos os objetos válidos de convenções processuais, faz-se necessário prosseguir com o estudo até a consolidação por parte da jurisprudência. Enquanto isso, a doutrina segue ponderando as hipóteses.

Para Fernando da Fonseca e outros autores, é vedado:

\footnotetext{
${ }^{7}$ TARTUCE, Flávio. Direito civil: lei de introdução e parte geral. 10. ed. São Paulo: Método, 2014. p. 270.
} 
(i) Dispensar o dever de motivação das decisões judiciais; (ii) a suprimir o contraditório ou o direito de defesa; (iii) a impor o segredo de justiça no trâmite do processo; (iv) a admitir a validade de prova ilícita; ou (v) disciplinar, de modo diverso da $\mathrm{CF}$, regras de competência absoluta e/ou viabilizadoras do juiz natural (v.g., escolhendo previamente determinada vara ou juiz para o julgamento da causa); têm objeto ilícito e, como tal, são nulas de pleno direito (o Enunciado n. ${ }^{\circ} 20$ do FPPC estabelece, entre outros, que não são admissíveis negócios processuais para modificação de competência absoluta ou supressão da $1 .^{a}$ instância). Aplica-se, aqui, a limitação constante tanto da lei civil (artigo 2.035, parágrafo único, CC) quanto da Lei de Arbitragem (artigos $2 .^{\circ}, \S 1 .^{\circ}$, e $21, \S$ $2 .^{\circ}$, da Lei n. ${ }^{\circ}$ 9.307/1996), no sentido de que são nulas as convenções cujo teor viole as garantias constitucionais do processo, os costumes e a ordem pública. Ordem pública que também é violada quando as partes, por exemplo, dispensam-se, reciprocamente, do dever de cooperação (artigo 6. ${ }^{\circ}$ do CPC/2015), de boa-fé e de lealdade processual (artigos $5 .^{\circ}$ e 77 do CPC/2015), temas que também não podem ser convencionados pelas partes em vista da ilicitude de seu objeto ${ }^{8}$.

\title{
Em complemento, Rogéria Dotti aduz:
}

\begin{abstract}
A propósito, o Fórum Permanente de Processualistas Civis (FPPC), grupo formado por professores de processo civil de todo o Brasil, já vem se manifestando a respeito da admissibilidade dos seguintes negócios processuais: pacto de impenhorabilidade, acordo para ampliação ou redução de prazos das partes de qualquer natureza, dispensa consensual de assistente técnico, convenção para afastar a possibilidade de execução provisória, dentre outros. Merece destaque o Enunciado 06: "o negócio jurídico processual não pode afastar os deveres inerentes à boa-fé e à cooperação". Obviamente, a implementação do negócio processual deve obedecer certos limites, não podendo as partes fazer acordo para modificação da competência absoluta e/ou acordo para supressão da primeira instância (Enunciado 20 do FPPC). Também não se pode acordar a não intervenção do Ministério Público ou a dispensa dos requisitos da petição inicial. Ainda, não será considerada válida convenção pré-processual oral ${ }^{9}$.
\end{abstract}

\section{Ainda que um rol extenso de possibilidades e vedações, do imaginário e das necessidades dos indivíduos surgirão diversas hipóteses ainda não estudadas, de modo que a doutrina continuará ponderando}

\footnotetext{
${ }^{8}$ GAJARDONI, Fernando da Fonseca et al. Teoria geral do processo: comentários ao CPC de 2015 parte geral. São Paulo: Forense, 2015. p. 1239.

${ }^{9}$ DOTTI, Rogéria; ANDREASSA JUNIOR, Gilberto. Normas fundamentais e negócios processuais no novo CPC. Revista Consultor Jurídico, 20 jan. 2016. Disponível em $\langle$ http://www.conjur.com.br/2016-jan-20/normas-fundamentais-negocios-processuais-cpc〉. Acesso em: 13 ago. 2018.
} 
incansavelmente enquanto aguarda o surgimento de casos concretos pelo meio judicial.

\subsubsection{FORMA}

Prevista tanto no inciso III do artigo 104 quanto no artigo 166 do Código Civil, a forma é um requisito essencial do negócio jurídico. Não obstante a omissão do Código Processual Civil no que diz respeito à forma exigida para a realização de um negócio jurídico processual, entende-se que o mínimo a ser respeitado é a forma escrita.

Justifica-se a exigência da forma escrita equilibrando a liberdade da forma à segurança jurídica, em complemento ao devido processo legal, tutelado pela Constituição Federal.

Pode constar, portanto, de contrato anterior ao processo ou ainda no bojo processual, inclusive oralmente em audiências, devendo, nesse caso, ser reduzido a termo ${ }^{10}$.

\subsubsection{PRESERVAÇÃO DA AUTONOMIA DA VONTADE}

A autonomia da vontade significa que uma manifestação de vontade livre e desimpedida deve ter sua validade respeitada.

No bojo do processo civil, resulta que o juiz somente poderá recusar a aplicação do negócio jurídico processual quando identificar casos de nulidade ou inserção abusiva em contrato de adesão, bem como quando alguma parte se encontrar em manifesta situação de vulnerabilidade.

Outro desdobramento é que as convenções acordadas com vícios de consentimento deverão ser invalidadas, por força do artigo 171 do Código de Processo Civil.

Entre os vícios do consentimento, cita-se o erro, o dolo, a coação, o estado de perigo, a lesão e a fraude contra credores. Podem levar à anulação da convenção processual, sendo esta, portanto, anulável, não nula, com prazo decadencial de quatro anos.

\footnotetext{
${ }^{10}$ GAJARDONI, Fernando da Fonseca et al., op. cit., p. 1240, nota 6.
} 


\subsubsection{DIREITOS DISPONÍVEIS}

Os direitos que admitem autocomposição são os disponíveis. Assim, como se vislumbra na Arbitragem, os direitos indisponíveis devem ser levados à apreciação do judiciário, não podendo configurar objeto de arbitragem ou de convenção processual.

Em complemento, ressalta-se que ainda que o juiz declarar a validade do negócio jurídico processual, por respeitar a todos os requisitos dissecados anteriormente, este deverá ser arguido no momento adequado, sob pena de preclusão.

Portanto, a convenção processual estará em plena validade quando passar pelo crivo do juiz e quando for arguida no momento adequada, configurando sua força vinculante e executiva.

Elucidadas, pois, os requisitos legais do instituto em questão, necessário se faz passar ao estudo principiológico, a fim de aprofundar o balizamento da autonomia das partes.

\section{DOS PRINCÍPIOS}

Diversos são os princípios do ordenamento jurídico brasileiro, porém nem todos se fazem essenciais à temática, de modo que serão citados os mais importantes, respeitando a divisão de princípios regentes do novo código de processo civil, nascidos geralmente dos princípios constitucionais do processo, e de princípios do direito contratual.

\subsection{DOS PRINCÍPIOS REGENTES DO NOVO CÓDIGO DE PROCESSO CIVIL}

É pertinente iniciar o estudo dos Princípios do Processo Civil com os Princípios do Contraditório e da Ampla Defesa, previstos no inciso LV do artigo 5. ${ }^{\circ}$ da Constituição Federal.

Não obstante sejam frequentemente tratados como um só princípio, eles se dividem em dois aspectos diferentes: $O$ contraditório significa a participação efetiva da parte no processo, enquanto a ampla defesa se afunila à maneira que essa participação materializar-se-á. 
Os litigantes devem, então, ter a oportunidade de participar do procedimento judicial, utilizando os instrumentos processuais a fim de alcançar o juiz.

Assim, a ampla defesa representa um conjunto de recursos que instrumentalizam o contraditório.

Tanto o contraditório quanto a ampla defesa são assegurados aos acusados em geral, de forma que negócios jurídicos processuais que tendam a mitigar essas garantias não podem ter sua validade afirmada.

O Princípio da Publicidade, do inciso LX do artigo $5 .^{\circ}$ e do inciso IX do artigo 93 da Constituição Federal, assegura ao público o acesso aos processos em geral, vedando-o apenas quando a lei o restringir, nos casos de defesa da intimidade ou quando o interesse social o exigir. Tal princípio veda os julgamentos secretos e assegura à população a fiscalização da prestação jurisdicional.

Como a própria redação constitucional estipulou, só a lei poderá restringir a publicidade, de modo que negócios jurídicos processuais que o intentem não são válidos. Se as partes tiverem interesse na resolução de seus conflitos com privacidade, devem optar pelo procedimento arbitral, em não se tratando de direitos indisponíveis.

Já o Princípio da Motivação Judicial, previsto no inciso IX do artigo 93 da Constituição Federal, obriga os julgadores dos órgãos do Poder Judiciário a fundamentarem suas decisões, de maneira a esclarecerem o direito aos litigantes. $O$ único ato judicial que prescinde de fundamentação é o despacho, pois não tem caráter decisório. É uma garantia aos sucumbentes que almejem interpor recurso, pois sem fundamentação não há como atacar a decisão. O dever de fundamentação do magistrado igualmente não pode ser afastado por meio de negócio jurídico processual.

Em complemento, há o Princípio da Igualdade Processual, que decorre do Princípio da Imparcialidade do Juiz. Este estabelece que o juiz deve permanecer em posição equidistante entre autor e réu, sendo defeso que manifeste inclinação por uma em detrimento de outra. Assim, o juiz deve permanecer imparcial, ao mesmo tempo em que as partes devem possuir condições equivalentes na relação processual.

A igualdade tratada no princípio é a igualdade material, que significa a equidade entre as partes. Significam que as diferenças de cada uma devem ser levadas em consideração a fim de estabelecer uma igualdade de condições, tratando cada qual desigualmente na proporção de suas desigualdades. 
A real igualdade entre as partes não poderá ser mitigada por meio de convenção processual.

O Princípio da Cooperação, novidade do novo CPC, com previsão em seu artigo $6 .^{\circ}$, aduz que todos os sujeitos do processo devem colaborar para uma decisão de mérito justa e efetiva em tempo razoável. Luiz Rodrigues Wambier e Eduardo Talarini apontam:

\begin{abstract}
Não se ignora o antagonismo estabelecido entre as partes. Tampouco se pode desconsiderar que, em primeiro lugar, cada parte tem o direito de, nos limites da boa-fé, exercer todas as faculdades processuais possíveis para obter no processo o resultado que lhes seja o mais favorável possível. No entanto, nada disso afasta a consideração de que o único objeto a que legitimamente se pode aspirar no processo é uma tutela jurisdicional justa e oportuna. Esse escopo é idêntico para todos os sujeitos do processo - e ele serve de pauta e meta para o dever de cooperação ${ }^{11}$.
\end{abstract}

Conclui-se, portanto, que as partes devem atuar regidos pela boafé, enquanto o juiz deve atuar com transparência e visando à efetiva solução da lide.

A previsão do negócio jurídico processual no bojo do Código de Processo Civil está em perfeita consonância ao Princípio da Cooperação. Contraditório seria, pois, uma estipulação das partes que viesse a contrariálo. Exemplifica-se com uma cláusula que expressa que o ônus da prova incumbe exclusivamente a um dos litigantes. No caso de cristalina hipossuficiência dessa parte, por óbvio que a convenção seria contrária ao dever de cooperação no processo, resultando na invalidade do negócio jurídico processual.

Por fim, deve-se dissecar o Princípio do Devido Processo Legal.

Em vista que, pelo Princípio do Acesso à Justiça, o lesionado pode recorrer ao Poder Judiciário para buscar o atendimento de seu direito, o Estado-Juiz deve buscar condições para que sua atividade jurisdicional possa atender a quem recorre a ela. Essa atividade, portanto, é regulamentada em prol da eficiência do serviço público, eficiência essa que deve ser conjugada à efetividade, servindo, de fato, ao indivíduo que buscou a solução da lide por meio do processo. Para tal, são estabelecidas condições mínimas nas quais o procedimento deve se apoiar.

O conjunto dessas condições mínimas forma o Devido Processo Legal, traduzido em diversos outros princípios, como escreve Fredie Didier Jr.:

${ }^{11}$ WAMBIER, Luiz Rodrigues; TALARINI, Eduardo, op. cit., p. 83, nota 3. 
É preciso observar o contraditório e a ampla defesa (art. $5^{\circ}, \mathrm{LV}$, $\mathrm{CF} / 1988$ ) e dar tratamento paritário às partes do processo (art. $5^{\circ}$, I, CF/1988); proíbem-se provas ilícitas (art. 5, LVI, CF/1988); o processo há de ser público (art. $5^{\circ}, \mathrm{LX}, \mathrm{CF} / 1988$ ); garante-se o juiz natural (art. $5^{\circ}$, XXXVII e LIII, CF/1988); as decisões hão de ser motivadas (art. 93, IX, CF/1988); o processo deve ter uma duração razoável (art. $5^{\circ}$, LXXVIII, CF/1988); o acesso à justiça é garantido (art. $5^{\circ}, \mathrm{XXXV}, \mathrm{CF} / 1988$ ) etc. Todas essas normas (princípios e regras) são concretizações do devido processo legal e compõem o seu conteúdo mínimo ${ }^{12}$.

Essas condições mínimas não podem ser mitigadas por meio de negócio jurídico processual, já que representaria um retrocesso aos conteúdos processuais sedimentados, além de ferir a insegurança jurídica.

Assim, toda e qualquer convenção processual deve observar a todos os princípios aqui estudados para que tenham a validade confirmada pelo juiz, pois as partes podem ajustar o procedimento judicial às suas necessidades desde que não lesionem o processo, um tutelado pela Constituição Federal.

\subsection{DOS PRINCÍPIOS DO DIREITO CONTRATUAL}

Os princípios do direito constitucional existem porquanto balizam as estipulações individuais a uma margem de aceitação social. Por certo que se tratam de interesses majoritariamente privados, porém mesmo na esfera particular as partes devem obedecer a certos regramentos, como se verá a seguir.

De início, é importante discorrer sobre o Princípio da Autonomia da Vontade. Pelas possibilidades infinitas de de relações humanas, entende-se que os indivíduos possuem liberdade de contratar, decidindo os sujeitos que integrarão o contrato, quando este se dará e sobre o que versará.

Não obstante, o Princípio da Autonomia da Vontade concilia as intenções dos contratantes com suas respectivas capacidades de se reafirmarem na negociação, não marginalizando a parte menos vulnerável.

Assim, a liberdade de contratar demonstra-se ilimitada, enquanto a autonomia da vontade tem sua limitação no artigo 421 do Código Civil. Nas palavras de Fábio Ulhoa Coelho, "o princípio da autonomia privada não é ilimitado. Balizam-no a ordem pública, a moralidade, a proteção da

\footnotetext{
${ }^{12}$ DIDIER JÚNIOR, Fredie. Curso de direito processual civil. 17. ed. Salvador: Juspodivm. p. 66.
} 
vontade livre e consciente das partes e dos contratantes débeis"13. A autonomia da vontade, em conseguinte, representa o fundamento do negócio jurídico processual.

Já o Princípio da Obrigatoriedade dos Contratos significa a "irreversibilidade da palavra empenhada"14, representando que uma vez expressa e contratada a vontade, o manifestante não pode se escusar de cumprir o avençado. Verifica-se pela necessidade de segurança dos negócios jurídicos, que tem sua força configurada pelo acordo das partes.

A mudança do acordado só se dará em situações excepcionais, por exemplo, por desequilíbrio das prestações quando acontecimentos imprevisíveis acarretarem uma onerosidade excessiva a alguma das partes.

Os negócios jurídicos processuais, por outro lado, exigem a atuação jurisdicional, de ofício ou a requerimento, para que tenham sua validade decretada, podendo recusar-lhes aplicação nos seguintes casos: nulidade ou inserção abusiva em contrato de adesão ou nos casos em que se verifique a manifesta situação de vulnerabilidade de uma das partes. A atuação judicial, portanto, é limitada a hipóteses específicas.

Coelho:

Quanto ao Princípio da Boa Fé Objetiva, para Fábio Ulhoa

Agir de boa-fé, entenda-se, não significa passar a defender, nas negociações, os interesses do outro contratante. Isso não se exige de ninguém e seria um extraordinário contrassenso: cada um continua perseguindo os seus próprios interesses ao contratar e não precisa abrir mão deles. É necessário, contudo, que as partes nutram mútuo respeito, que prestem sempre informações completas, claras e verdadeiras, não enganem nem busquem ocultar com subterfúgios aspectos essenciais ao negócio (Silva, 1976). Se as ações ou omissões de um sujeito denunciam ou sugerem desrespeito aos direitos do outro contratante, considera-se que ele descumpriu o dever geral de boa-fé objetiva ${ }^{15}$.

Assim, resta esclarecido que a boa fé está intrinsecamente ladeada ao Princípio da Cooperação e que deve ser observada desde a formação do contrato até o final da relação jurídica, inclusive a processual, caso venha a ser instaurada.

Por fim, necessário dissecar o Princípio da Função Social do Contrato. Um contrato personifica uma relação entre particulares, com seus

\footnotetext{
${ }^{13}$ COELHO, Fábio Ulhoa. Curso de direito civil: contratos. 5. ed. São Paulo: Saraiva, 2012. p. 67.

${ }^{14}$ GONÇALVES, Carlos Roberto. Direito civil brasileiro: contratos e atos unilaterais. 15. ed. São Paulo:

${ }^{15}$ COELHO, Fábio Ulhoa, op. cit., p. 84, nota 11.
} 
interesses privados, mas mesmo assim deve observar o interesse geral, conforme disposto no artigo 421 do Código Civil, aplaudido por diversos países latinoamerianos que não preveem explicitamente a função social do contrato em seus ordenamentos jurídicos.

Sabe-se que o direito de uma pessoa termina onde começa o de outra pessoa. Assim, apesar de um contrato versar sobre interesses exclusivamente particulares, com efeitos limitados inter partes, pode ser que haja interesses de terceiros possivelmente lesados por negócios jurídicos que não firmaram eles mesmo. Em complemento, há avenças que lesionam normas sociais, acarretando a violação de um direito de todos, ainda que não atinja individualmente a ninguém.

Portanto, assim como a boa fé objetiva, a função social do contrato deve ser verificada desde o momento de formação deste até na sua interpretação.

Deste modo, os negócios jurídicos processuais, além de não agredirem ao processo, devem respeitar os princípios contratuais da mesma forma que um negócio jurídico qualquer o faz.

Em seguida, considerando todos os requisitos legais e os princípios já estudados, serão analisadas algumas hipóteses específicas de estipulações processuais em contratos de locação de imóveis urbanos.

\section{$4 \quad$ HIPÓTESES DE NEGÓCIOS JURÍDICOS PROCESSUAIS APLICADOS AOS CONTRATOS DE LOCAÇÃO DE IMÓVEIS}

Por força do artigo 2.036 do Código Civil, a locação de prédio urbano é regida pela lei especial: a Lei do Inquilinato, de n. ${ }^{\circ} 8.245 / 91$.

$\mathrm{O}$ artigo 565 do Código Civil conceitua locação da seguinte maneira: "Na locação de coisas, uma das partes se obriga a ceder à outra, por tempo determinado ou não, o uso e gozo de coisa não fungível, mediante certa retribuição".

As principais características de um contrato de locação, para Flávio Tartuce, são:

Contrato bilateral ou sinalagmático, uma vez que traz obrigações recíprocas. O contrato é oneroso, pela presença de remuneração (aluguel). Contrato comutativo, pois as partes já sabem quais são as prestações. Contrato consensual, eis que se aperfeiçoa com a manifestação de vontades. Contrato informal e não solene, pois não 
é necessária escritura pública ou forma escrita, como regra geral. Trata-se de típico contrato de execução continuada (ou de trato sucessivo), uma vez que o cumprimento se protrai no tempo na maioria das hipóteses fáticas ${ }^{16}$.

A Lei do Inquilinato, reitera-se, trata de locação de prédio urbano e prevê quatro procedimentos especiais: ação de despejo (artigos 59 a 66), ação de consignação de aluguel e acessórios de locação (artigo 67), ação revisional de aluguel (artigos 68 a 70) e ação renovatória (artigos 71 a 75).

Quando às principais mudanças causadas à Lei de Locações pelo advento do novo Código de Processo Civil, escreve Marcelo Mazzola algumas possibilidades de negócios jurídicos processuais:

\begin{abstract}
Apenas a título ilustrativo, podemos mencionar exemplos do que poderia ser convencionado pelo locador, pelo locatário e pelo fiador na fase contratual: cláusulas de paz (opção pelos métodos alternativos de solução de conflitos antes de eventual judicialização da matéria), de eleição de foro, de escolha do perito em eventual ação judicial, de ampliação de prazo para a denúncia da locação ou desocupação do imóvel em contrato por prazo indeterminado, de vistoria do imóvel, de impenhorabilidade de algum bem, de redistribuição do ônus da prova, de regras de sucumbência e divisão de despesas processuais, de renúncia bilateral de recurso etc.) ${ }^{17}$.
\end{abstract}

Não serão estudadas todas essas hipóteses levantadas, pois algumas não exigem um aprofundamento, como a eleição de foro, que já era adotada. Ademais, a renúncia do benefício de ordem, permitida no artigo 828, I, também se demonstra de rotina nos contratos de locação de imóveis urbanos, principalmente os usados pelas imobiliárias.

\title{
4.1 DIMINUIÇÃO OU AMPLIAÇÃO DE PRAZOS PROCESSUAIS
}

A primeira convenção a ser estudada é a modificação de prazos para cumprimento de atos processuais, seja ampliando-os ou os diminuindo. Por parte da doutrina, trata-se de questão pacífica, pois o $§ 1$. $^{\circ}$ do artigo 222 do Código de Processo Civil é cristalino ao dispor que "ao juiz é vedado reduzir prazos peremptórios sem anuência das partes". Assim, as partes podem, de comum acordo, convencionar prazos que

\footnotetext{
${ }^{16}$ TARTUCE, Flávio. Manual de direito civil. 7. ed. Rio de Janeiro: Forense; São Paulo: Método, 2017. p. 511

${ }^{17}$ MAZOLLA, Marcelo. As incursões do novo CPC na lei de locações. Revista do processo, v. 263, p. 285-312, jan. 2017.
} 
melhor ajustem o processo aos seus interesses, desde que não se trate de prazo diverso para ato judicial, que exige também a anuência do juiz.

\subsection{RENÚNCIA BILATERAL DE RECURSO}

De início, há um conflito entre o Princípio do Duplo Grau de Jurisdição e o recurso como ônus da parte.

O Princípio do Duplo Grau de Jurisdição não está previsto no texto constitucional, mas, para o direito processual penal, está expresso no Pacto de São José da Costa Rica. Apesar de não obrigatório o duplo grau de jurisdição na lei, tanto a estrutura do Poder Judiciário, que regula os graus de jurisdição e suas funções, quanto o Código de Processo Civil, que dispõe os recursos possíveis, leva à conclusão de que se trata de um direito aos litigantes.

Por outro lado, o direito de recorrer, assim como o direito de contestar, representa um ônus processual, pois não gera nenhuma sanção em caso de não interposição de recurso. O recurso, portanto, consiste em uma via judicial existente para a reapreciação da matéria controvertida pelo Poder Judiciário, existindo a possibilidade de se reformar a decisão. Será interposto pelo sucumbente quando lhe parecer pertinente.

Portanto, demonstra-se razoável que as partes, por meio de cláusula contratual, escolham que um conflito futuro seja apreciado apenas em primeira instância, pois o magistrado é competente para dizer o direito no caso concreto quando as partes escolhem a via judicial. De igual maneira, a renúncia bilateral a todos os recursos com exceção dos embargos de declaração, já prevendo a eventualidade da falibilidade humana, demonstra-se válida e capaz de conjugar os anseios dos interessados por celeridade e segurança jurídica.

Essa cláusula contratual, assim como as demais, deve ser alegada no momento oportuno pelo interessado, sob pena de preclusão, como ocorre com a cláusula de arbitragem.

\subsection{RENÚNCIA À AUDIÊNCIA DE CONCILIAÇÃO PRÉVIA}


A audiência de tentativa de conciliação trata-se de regra fixada pelo novo Código de Processo Civil, dispondo de rol taxativo de hipóteses nas quais não irá ocorrer, no $\S 4^{\circ}$ do artigo 334.

No inciso I, está previsto que a realização da audiência será dispensada no caso de negativa de ambas as partes. $\mathrm{O}$ autor deverá esclarecer o seu interesse ou desinteresse em sua realização na petição inicial, enquanto o réu o fará por simples petição, protocolada com antecedência mínima de dez dias da audiência.

Não obstante não haja previsão legal para que as partes manifestem o desinteresse anteriormente à instauração do processo, tal se vislumbra possível, pois os acordantes podem optar por maior celeridade processual, de modo a adiantar a fase instrutória.

É do entendimento dos autores Luiz Rodrigues Wambier e Eduardo Talamini que as partes podem celebrar negócio jurídico processual excluindo a realização da audiência de conciliação, durante o processo ou antes dele ${ }^{18}$.

Assim, uma cláusula em contrato de locação de imóvel residencial que estipule a renúncia à audiência de conciliação é entendida como válida, inclusive porque não vulnera nenhum princípio ou requisito legal.

\subsection{RENÚNCIA DA SUB-ROGAÇÃO DE DIREITOS EM CASO DE MORTE DO LOCATÁRIO DE IMÓVEL RESIDENCIAL}

Apesar de não integrar estritamente o âmbito processual, uma hipótese a ser levantada é a da possibilidade, haja vista a amplitude do dispositivo, de as partes acordarem por meio de negócio jurídico processual que não haverá a sub-rogação de direitos em caso de morte do locatário de imóvel residencial.

A transmissão da locação aos herdeiros quando da morte do locatário está consagrada no artigo 11 , I, da Lei n. ${ }^{\circ} 8.246 / 91$. Tem a finalidade de preservar o lar da entidade familiar, sub-rogando os direitos aos herdeiros sobreviventes em uma ordem específica: o cônjuge ou companheiro, em primeiro lugar, e posteriormente os herdeiros necessários e demais pessoas que convivam na dependência econômica do locatário falecido, com a condição de que residam no imóvel locado.

${ }^{18}$ WAMBIER, Luiz Rodrigues; TALARINI, Eduardo, op. cit., p. 129, nota 3. 
A renúncia desta sub-rogação não se justifica e não poderá ser validada pelo juiz por diversos motivos.

De início, conforme estudado, há um limite para a autonomia da vontade. $\mathrm{O}$ contrato instrumentaliza a vontade dos contratantes, mas deve respeitar a função social. O direito à moradia da família residente no imóvel deve prevalecer, se tratando a sub-rogação de norma de ordem pública, que deve ser observada por todos, principalmente porque inexistentes exceções no texto legal.

Em complemento, o contrato de locação não é um contrato personalíssimo. O que visa o locador é receber o aluguel em troca de dispor o seu imóvel a outrem. Ainda que, em tese, tal locação só se dê com locatário em específico por motivos pessoais do locador, a finalidade última continua o recebimento dos alugueis, do contrário poderia ser firmado um contrato de comodato. A onerosidade se mantém com a subrogação de direitos aos herdeiros, já que deverão cumprir o contrato nos moldes em que estabelecidos.

Por fim, o locador dispõe de inúmeros mecanismos para mitigar o inadimplemento dos novos locatários, não se justificando a renúncia da sub-rogação como forma de "proteção". Eventual cláusula contratual de renúncia à sub-rogação de direitos em caso de morte de locatário de imóvel residencial não deverá ser confirmada judicialmente, como modo de preservar uma norma de ordem pública que resguarda o interesse de terceiros.

\subsection{DESNECESSIDADE DE CAUÇÃO PARA A CONCESSÃO DE DESPEJO LIMINAR}

Diante de todas as possibilidades existentes de convenções processuais, que irão surgindo no mundo jurídico com o passar do tempo e à medida em que a criatividade dos contratantes permitirem, ain da não se faz possível catalogá-las.

No entanto, desde 2015 já se vislumbram alguns casos concretos discutidos no Poder Judiciário. A título de curiosidade, serão expostos dois julgados do Tribunal de Justiça do Estado de São Paulo que reafirmam a impossibilidade de se afastar a caução necessária à concessão de despejo liminar.

A 31. ${ }^{a}$ Câmara de Direito Privado, em julgado de relatoria de Paulo Ayrosa, decidiu: 
Bem por isso, não acode a locadora demandante, ora agravante, a invocação a "negócio jurídico processual" como fundamento para afastar expressa determinação legal que pressupõe a prestação de caução no valor equivalente a três (3) alugueis mensais para a concessão do despejo liminar ${ }^{19}$.

\title{
Consoante é o entendimento da $30 .^{a}$ Câmara de Direito Privado:
}

\begin{abstract}
AÇÃO DE DESPEJO POR FALTA DE PAGAMENTO NEGÓCIO JURÍDICO PROCESSUAL INOBSERVÂNCIA DA BOA-FÉ RELAÇÃO JURÍDICA DIAGONAL Cláusula que previu o "negócio jurídico processual" que se limitou a prever benefícios ao locador, como a redução dos prazos, desocupação do imóvel de forma imediata e sem garantia, recursos apenas com efeito devolutivo e custeio de eventuais provas sempre pelo locatário, a quem não foi prevista qualquer garantia ou vantagem. Em verdade, não se configurou negócio processual fruto de autonomia de vontades, mas sim de um modo de afastar a aplicação da lei específica quando esta se mostrava desfavorável ao autor da ação de despejo ou credor dos respectivos alugueis. Cláusula que dispensa o dever de prestar caução para fins de liminar que deve ser afastada. Declaração de invalidade que pode ser feita de ofício pelo julgador. RECURSO IMPROVIDO ${ }^{20}$.
\end{abstract}

\section{No corpo deste voto, ainda se expôs:}

Nota-se, inclusive, que especificamente no caso dos autos a cláusula que previu o "negócio jurídico processual" limitou-se a prever benefícios ao locador, como a redução dos prazos, desocupação do imóvel de forma imediata e sem garantia, recursos apenas com efeito devolutivo e custeio de eventuais provas sempre pelo locatário, a quem não foi prevista qualquer garantia ou vantagem. Em verdade, não se configurou negócio processual fruto de autonomia de vontades, mas sim de um modo de afastar a aplicação da lei específica quando esta se mostrava desfavorável ao autor da ação de despejo ou credor dos respectivos alugueis ${ }^{21}$.

\section{Esclareceu-se o direito no caso concreto, usando o juiz de seu poder de controle às convenções processuais para garantir a justiça e a boa} fé.

19 BRASIL. Tribunal de Justiça do Estado de São Paulo. Agravo de instrumento n. ${ }^{\circ} 2248811$ 80.2017.8.26.0000, 31. ${ }^{\text {a }}$ Câmara de Direito Privado, Relator Paulo Ayrosa, Agravante Kelly Cristina Messias Ferreira dos Santos, Agravada Lazara Helena da Silva, Julgamento: 31/01/2018, Publicação: 31/03/2018.

${ }^{20}$ BRASIL. Tribunal de Justiça do Estado de São Paulo. Agravo de instrumento n. ${ }^{\circ} 2233478$ 88.2017.8.26.0000, 30ª Câmara de Direito Privado, Relatora Maria Lúcia Pizzotti, Agravante Evelina Maria Pacheco de Faria Toledo Martinelli e Priscilla Andrea Penha Hamada, Agravado Marcelo Vezetiv Vieira Sandes, Julgamento: 21/03/2018, Publicação: 26/03/2018.

${ }^{21}$ BRASIL. Tribunal de Justiça do Estado de São Paulo, op. cit., nota 18. 
Assim, o próprio Poder Judiciário já está firmando o posicionamento no que diz respeito a este negócio jurídico processual em específico, com a justificativa de que afastar a caução necessária à concessão de despejo liminar configura meramente uma maneira de afastar a aplicação da lei, não representando um acerto de vontades, o que vai contra à intenção das convenções processuais.

\section{CONCLUSÃO}

O presente artigo se propôs a estudar os limites do negócio jurídico processual no tocante aos contratos de locação de imóveis urbanos. Para tal, dissecaram-se conceitos, requisitos legais e princípios que servem de escopo ao estudo das convençoes processuais, buscando balizar suas proporções.

Assim, conclui-se que não obstante o contrato de locação de imóvel urbano diga respeito a interesses principalmente particulares, a autonomia das partes deve respeitar normas de ordem pública e interesses de terceiros, bem como preceitos fundamentais ao processo.

É conclusivo, igualmente, que dentre as hipóteses levantadas, a renúncia à sub-rogação de direitos em caso de morte do locatário de imóvel residencial não se verifica possível, pois lesa a função social do contrato, prejudicando o direito à moradia da família sobrevivente.

Interessante observar, também, que no caso de dispensa da caução necessária à concessão de despejo liminar o Tribunal de Justiça do Estado de São Paulo já solidificou o seu entendimento, negando a validade deste negócio jurídico processual, por entender ser meramente uma forma de contornar expressa previsão legal.

Em consonância, é de bom tom constatar que o legislador não exauriu as possibilidades de negócios jurídicos processuais, o que explicita a amplitude do referido dispositivo, que deve estar sempre ladeado aos princípios e requisitos legais anteriormente estudados para que tenham sua validade confirmada pelo juiz.

Assim, faz-se necessário aguardar o advento de novas transações pelos acordantes, que irão demonstrar suas necessidades ajustando o procedimento judicial da melhor maneira que lhes aprouver. Caso não seja o negócio jurídico processual validado judicialmente, ao menos pugnouse. Na atual conjuntura, é questão de tentativa e erro. 


\section{REFERÊNCIAS BIBLIOGRÁFICAS}

BRASIL. Lei n. 8.245, de 18 de outubro de 1991. Dispõe sobre as locações dos imóveis urbanos e os procedimentos a elas pertinentes. Brasília, DF, 18 out. 1991. Disponível em:

<http://www.planalto.gov.br/ccivil_03/leis/L8245.htm>. Acesso em: 16 nov. 2017.

BRASIL. Lei n. 10.406, de 10 de janeiro de 2002. Institui o Código Civil. Brasília, DF, 10 jan. 2002. Disponível em: <http://www.planalto.gov.br/ccivil_03/leis/2002/L10406.htm〉. Acesso em: 16 nov. 2017.

BRASIL. Lei n. 13.105, de 16 de março de 2015. Código de Processo Civil. Brasília, DF, 16 mar. 2015. Disponível em: <http://www.planalto.gov.br/ccivil_03/_ato2015-2018/2015/lei/113105.htm>. Acesso em: 16 nov. 2017.

BUENO, Cassio Scarpinella. Manual de direito processual civil. São Paulo: Saraiva, 2015.

COELHO, Fábio Ulhoa. Curso de direito civil: contratos. 5. ed. São Paulo: Saraiva, 2012.

DIDIER JÚNIOR, Fredie. Curso de direito processual civil. 17 ed. Salvador: Juspodivm, 2015.

Negócios jurídicos processuais atípicos no Código de Processo Civil de 2015. Revista Brasileira de Advocacia, v. 1, abr./jun. 2016. Disponível em:

<http://www.mpsp.mp.br/portal/page/portal/documentacao_e_divulgacao/doc_biblioteca/bibli_servic os_produtos/bibli_boletim/bibli_bol_2006/RBA_n.01.04.PDF>. Acesso em: 20 maio 2018.

DINIZ, Maria Helena. Curso de direito civil brasileiro: Teoria Geral do Direito Civil. São Paulo: Saraiva, 2012.

DOTTI, Rogéria; ANDREASSA JUNIOR, Gilberto. Normas fundamentais e negócios processuais no novo CPC. Revista Consultor Jurídico, 20 jan. 2016. Disponível em $\langle$ http://www.conjur.com.br/2016-jan-20/normas-fundamentais-negocios-processuais-cpc $>$. Acesso em: 06 abr. 2017.

DUARTE, Antonio Aurélio Abi Ramia. Negócios processuais e seus novos desafios. Revista dos Tribunais, v. 955, p. $211-227$, maio 2015.

FARIA, Raphael. Novo CPC e a lei de locações. Jusbrasil, 2016. Disponível em:

$<$ https://raphaelgfaria.jusbrasil.com.br/artigos/377220571/novo-cpc-e-a-lei-de-locacoes >. Acesso em: 09 maio 2018.

FARIAS, Cristiano Chaves de; ROSENVALD, Nelson. Curso de direito civil: parte geral e LINDB. 13. ed. São Paulo: Atlas, 2015.

FERNANDES, Renata Assalim. Negócios jurídicos processuais no novo CPC: o que pode?. Migalhas, 19 maio 2017. Disponível em: <http://www.migalhas.com.br/dePeso/16,MI258990,71043 Negocios+juridicos+processuais+no+novo+CPC+o+que+pode>. Acesso em: 16 nov. 2017.

GAJARDONI, Fernando da Fonseca et al. Teoria geral do processo: comentários ao CPC de 2015 parte geral. São Paulo: Forense, 2015. 
O negócio jurídico processual a favor do Poder Judiciário. Jota, 30 nov. 2015. Disponível em: <https://jota.info/colunas/novo-cpc/o-negocio-juridico-processual-a-favor-da-eficiencia-dopoder-judiciario-30112015 >. Acesso em: 06 abr. 2017.

GONÇALVES, Carlos Roberto. Direito civil brasileiro: parte geral. 11. ed. São Paulo: Saraiva, 2013, v. 1 .

book.

Direito civil brasileiro: contratos e atos unilaterais. 15. ed. São Paulo: Saraiva, 2018, v. 3. E-

LÔBO, Paulo. Direito civil: contratos. 4. ed. São Paulo: Saraiva, 2018, v. 3. E-book.

MACHADO, Marcelo Pacheco. O negócio processual de renúncia à impenhorabilidade. Jota, 14 nov. 2016. Disponível em: <https://www.jota.info/opiniao-e-analise/colunas/novo-cpc/novo-cpc-enegocio-processual-de-renuncia-impenhorabilidade-14112016>. Acesso em: 09 maio 2018.

MAZOLLA, Marcelo. As incursões do novo CPC na lei de locações. Revista do processo, v. 263, p. 285-312, jan. 2017.

MEDINA, Paulo Roberto de Gouvêa. Teoria geral do processo. 3. ed. Salvador: Juspodivm, 2017.

NONN, Amanda. O novo código de processo civil e direito imobiliário. Entendeu Direito?

Disponível em: 〈https://amandanonn.wordpress.com/2017/06/20/o-novo-codigo-de-processo-civil-eo-direito-imobiliario-novo-cpc>. Acesso em: 09 maio 2018.

OLIVEIRA, Graciela Peripolli; ANDRADE, Marcelo Lasperg de. A igualdade aristotélica na ordem constitucional brasileira. JICEX, Curitiba, v. 3, n. 3, 2014. Disponível em:

<http://www.santacruz.br/ojs/index.php/JICEX/article/view/501>. Acesso em: 08 maio 2018.

PANJOTA, Barbara Bruna Rodrigues de Souza Guedes Alves. Impenhorabilidade do bem de família. Âmbito Jurídico. Disponível em: <http://www.ambito-

juridico.com.br/site/index.php?n_link=revista_artigos_leitura\&artigo_id=19256\&revista_caderno=14 >. Acesso em: 09 maio 2018.

PERES, Fernando. Sistema principiológicos no novo CPC: comentários dos artigos $1^{\circ}$ ao 12 . Jus, jul. 2015. Disponível em: < https://jus.com.br/artigos/40949/sistema-principiologico-no-novo-cpccomentarios-dos-artigos-1-ao-12>. Acesso em: 17 nov. 2017.

PIMENTEL, Alexandre Freire; MOTA, Natália Lobo. Negócios processuais atípicos: alcances e limites no CPC/2015. Âmbito Jurídico. Disponível em: <http://www.ambito-

juridico.com.br/site/?n_link=revista_artigos_leitura\&artigo_id=18199>. Acesso em: 19 nov. 2017.

ROUSSEAU, Jean-Jacques. Do contrato social. Versão para e-book. Disponível em:

<http://www.ebooksbrasil.org/adobeebook/contratosocial.pdf〉. Acesso em 11 jul. 2018.

SILVA, Julio César Ballerini. Considerações a respeito do negócio jurídico processual. Jus, 07 jul. 2016. Disponível em: <https://jus.com.br/artigos/50357/consideracoes-a-respeito-do-negociojuridico-processual>. Acesso em: 16 nov. 2017. 
TARTUCE, Flávio. Direito civil: lei de introdução e parte geral. 10. ed. Rio de Janeiro: Forense; São Paulo: Método, 2014.

Direito civil: teoria geral dos contratos e contratos em espécie. 12. ed. Rio de Janeiro: Forense; São Paulo: Método, 2017.

. Manual de direito civil. 7. ed. Rio de Janeiro: Forense; São Paulo: Método, 2017.

TAVARES JUNIOR, Homero Francisco. Aspectos da cláusula geral de negócios jurídicos processuais e do calendário processual previstos no Novo Código de Processo Civil (arts. 190 e 191). Belo Horizonte. Disponível em <http://www.tjmg.jus.br/data/files/A8/E4/25/F7/38B945107DBFA945ED4E08A8/Revisado\%20 $\% 20$ Aspectos $\% 20$ da $\% 20$ clausula $\% 20$ geral\%20de\%20negocios\%20juridicos\%20...\%20_artigos \%201 90\%20e\%20191_.pdf>. Acesso em: 06 abr. 2017.

VENOSA, Silvio de Salvo. Direito civil: parte geral. 13. ed. São Paulo: Atlas, 2013.

WALD, Arnoldo. Direito civil: contratos em espécie. 20. ed. São Paulo, Saraiva, 2015, v. 3. E-book.

WAMBIER, Luiz Rodrigues; TALAMINI, Eduardo. Curso avançado de processo civil: teoria geral do processo. 16. ed. São Paulo: Revista dos Tribunais, 2016. 